\title{
Climate Change and Justice: A Non-Welfarist Treaty Negotiation Framework
}

\section{Alyssa R. Bernstein}

To cite this article: Alyssa R. Bernstein (2015) Climate Change and Justice: A NonWelfarist Treaty Negotiation Framework, Ethics, Policy \& Environment, 18:2, 123-145, DOI: 10.1080/21550085.2015.1070519

To link to this article: http://dx.doi.org/10.1080/21550085.2015.1070519

册 Published online: 26 Nov 2015.

Submit your article to this journal $\pi$

Q View related articles $\widetilde{ }$

View Crossmark data \lceil 


\title{
Climate Change and Justice: A Non-Welfarist Treaty Negotiation Framework
}

\author{
ALYSSA R. BERNSTEIN \\ Philosophy Department, Ohio University, Athens, Ohio, USA
}

ABSTRACT Obstacles to achieving a global climate treaty include disagreements about questions of justice raised by the UNFCCC's principle that countries should respond to climate change by taking cooperative action "in accordance with their common but differentiated responsibilities and respective capabilities and their social and economic conditions". Aiming to circumvent such disagreements, Climate Change Justice (2010) authors Eric Posner and David Weisbach argue against shaping treaty proposals according to requirements of either distributive or corrective justice. The USA's climate envoy, Todd Stern, takes a similar position. In this article I explain the practical and theoretical drawbacks of Posner \& Weisbach's welfarist (utilitarian) perspective and propose an alternative. I show that their arguments fail to rule out John Rawls's non-utilitarian, political conception of international justice and human rights, the Law of Peoples. On this basis I develop a conception of climate justice that highlights implications of some of Rawls's principles and adds a principle for determining fair shares of climate-treaty-related benefits and burdens. I propose this conception as a moral framework for negotiating a treaty that would promote human welfare consistently with requirements of justice, and I argue that a treaty proposal satisfying these requirements could best satisfy Posner \& Weisbach's own feasibility criteria.

Among the obstacles to achieving a global climate treaty are disagreements about questions of corrective and distributive justice, such as those involved in discussions about how to interpret a particularly important idea in the United Nations Framework Convention on Climate Change (UNFCCC) of 1992: the principle that countries should respond to climate change by taking cooperative action 'in accordance with their common but differentiated responsibilities and respective capabilities and their social and economic conditions' (abbreviated as 'CBDR' or as 'differentiation'). Eric Posner and David Weisbach (2010), authors of Climate Change Justice, aim to remove those obstacles in order to avert the tragedy that could result from failure to achieve a global climate treaty. They argue that the negotiators should not shape treaty proposals to meet requirements of distributive or corrective justice, but should instead focus on practical matters such as comparing proposed mitigation measures with regard to aggregate global costs and benefits, and creating incentives sufficient to ensure that all countries will join the treaty.

Correspondence Address: Alyssa R. Bernstein. Ellis Hall 202, Ohio University, Athens, OH 45701, USA. Email: bernstei@ohio.edu, bastinbernstein@gmail.com 
According to Posner and Weisbach, treaty proposals should be efficient and feasible. More specifically, they should satisfy two criteria: the economic requirement of global optimality $^{1}$ and the pragmatic constraint of International Paretianism, which the authors define thus: 'all states must believe themselves better off by their lights as a result of the climate treaty' (Posner \& Weisbach, 2010, p. 6). ${ }^{2}$ They argue also that all countries (and in particular all 'major emitting countries') have obligations to join a climate agreement and not to free-ride (Posner \& Weisbach, 2010, pp. 181-183). They base their conclusions on a type of welfarism. ${ }^{3}$

Posner and Weisbach's arguments appear to provide support for a position taken recently by the United States' Special Envoy for Climate Change, Todd Stern, on the question of how to interpret CBDR. Stern advocates a forward-looking climate treaty, as explained below. Similarly, Posner and Weisbach oppose using principles of corrective justice, which are backward-looking, to design a climate treaty. Here I critically analyze their arguments and propose an alternative, a non-welfarist moral framework for the climate treaty negotiations.

Posner and Weisbach focus their attention mainly on the difficulties of designing an international climate treaty. I agree with them about the need for such a treaty; ${ }^{4}$ taking this as given, I focus as they do on the question they think 'may be the most difficult': that of how the burdens of mitigation or abatement measures should be distributed (Posner \& Weisbach, 2010, p. 3). States disagreeing with each other on this question have invoked various principles of justice. According to Posner and Weisbach (2010, p. 4), the central arguments about justice are vulnerable to serious objections of principle; furthermore, because their proponents fail to give due consideration to pragmatic or feasibility constraints, they threaten to derail a climate agreement and thus to hurt the nations and people who are pressing those very arguments. I agree with Posner and Weisbach when they say that the challenge is to construct a treaty that is both feasible and ethical, promoting the welfare of people all over the world consistently with the requirements of justice (Posner \& Weisbach, 2010, pp. 4-5). However, I disagree with their welfarist theoretical approach to this problem $^{5}$ and with their conception of distributive justice. ${ }^{6}$

There are practical as well as theoretical drawbacks to Posner and Weisbach's welfarist approach to these issues and, more generally, to basing the climate treaty negotiations ultimately on welfarist, utilitarian, or other consequentialist moral principles. Since the negotiations are authorized by international law and are further developing it by creating new legal obligations, they should be conducted in accordance with the principles grounding the rights and obligations of the negotiating states, including those they have in the negotiation process and would have under the treaty. The negotiations should be based on a political conception of justice that can be the focus of an overlapping consensus, the need for which has been emphasized recently by prominent philosophers criticizing the position of Posner and Weisbach (Jamieson, 2013, p. 467; Nussbaum, 2013, p. 485).

An example of a political conception of justice is John Rawls' conception of the moral basis of a just international order, the Law of Peoples (presented in Rawls, 1993, 1999). ${ }^{7}$ Its principles are formulated to apply to international law and practice, and it can be the focus of an overlapping consensus. As I explain below, it is a conception of distributive justice in the broader of the two senses of the term ('distributive justice') that Rawls distinguishes, but not in the narrower sense used by Posner and Weisbach; for this reason among 
others, their arguments against allowing principles of distributive justice to constrain treaty negotiations fail to apply to the Law of Peoples.

Below I briefly develop a political conception of climate justice based on the Law of Peoples, and argue that it has both theoretical and practical advantages over welfarism as a moral framework for the climate treaty negotiations. I use arguments informed by the writings of Jean-Jacques Rousseau (on social and international cooperation for the common good) and Immanuel Kant (on moral agency, obligation, and cosmopolitanism). ${ }^{8}$ I use some of Rawls' concepts and arguments, emphasize climate-change-relevant implications of some of the principles of the Law of Peoples, and add a principle for determining fair shares of climate-treaty-related benefits and burdens.

I contend that this political conception of climate justice is appropriate to serve as a moral framework for the climate treaty negotiations. ${ }^{9}$ Treaty proposals should satisfy the requirements of its principle for determining fair shares of the costs and other burdens of mitigation and adaptation measures. No treaty proposal justifiable on welfarist grounds should be considered globally optimal unless it is consistent with this political conception of justice. A treaty proposal that satisfies its requirements can also satisfy Posner and Weisbach's treaty criteria of International Paretianism and feasibility, indeed better than proposals justifiable only in terms of welfarism, as I argue below.

\section{Obstacles to Achieving a Global Climate Treaty}

A major obstacle to achieving an agreement at the climate treaty negotiations in Lima, Peru (in December 2014) was what participants and commentators referred to as the 'differentiation' issue (Taraska \& Vogel, 2014). Two months prior to the Lima conference, the United States' Special Envoy, Todd Stern, referred to this issue in a speech, saying that 'the most important' obstacle concerns how to interpret CBDR, which is 'the core principle asserted by developing countries'. ${ }^{10}$ The UNFCCC says that developed countries need to 'take immediate action' and should 'take the lead in combatting climate change' while allowing poorer countries to develop and acknowledging that 'their energy consumption will need to grow.' Although in Lima the negotiators finally agreed upon a text, the issue is expected to arise again at the negotiations in Paris in December 2015 (Taraska \& Vogel, 2014).

In his speech, Stern opposed the idea that the 1992 categorization of countries should be included in the new agreement because climate change is the developed countries' fault: 'that approach isn't going to advance the ball because developed countries don't accept that worldview, and because descending into that kind of debate at this stage is the last way to find common ground.' To insist on basing the new agreement 'in form or content on immutable 1992 categories' would be 'a deal-breaker,' he declared; instead of using a 'backwards-facing structure,' it is necessary to 'build our new agreement looking forward, to reflect the economic, political and environmental realities of the next decade and beyond.' Stern's position appears justifiable when considered within the welfarist framework advocated by Posner and Weisbach. However, as I explain next, this framework has theoretical, moral, and practical drawbacks, while the political conception of climate justice has corresponding advantages. Later I will return to the disagreement about differentiation, and suggest that the political conception of climate justice provides appropriate guidance for resolving this issue. 


\section{Posner and Weisbach's Welfarist Perspective}

Despite the title of their book, Climate Change Justice, Posner and Weisbach (2010, p. 5) argue that considerations of (in)justice should not shape a climate treaty:

Many people argue that the climate treaty should reflect principles of corrective and distributive justice. They treat climate negotiations as an opportunity to solve some of the world's most serious problems - the admittedly unfair distribution of wealth across northern and southern countries, the lingering harms of the legacy of colonialism, and so forth. We reject this approach.

They contend that a climate treaty should meet neither requirements of corrective justice $^{11}$ nor requirements of distributive justice. ${ }^{12}$ They favor 'a forward-looking, welfarist approach to the problem of climate change that satisfies pragmatic constraints' and 'takes the state system seriously by respecting International Paretianism’ (Posner \& Weisbach, 2010, p. 191).

Posner and Weisbach's (2010, p. 192) central contention is that it would be 'a cruel irony if the consequence of justice-related arguments were to doom the prospects for an international agreement - and thus to create exceedingly serious risks to human welfare, above all in poor nations'. They argue that if distributive justice is the goal, it is necessary to recognize that pursuing this goal through a climate treaty may not be the best way of redistributing wealth from rich countries to poor ones; but if climate harm mitigation is the goal, the best way to pursue it is by agreeing to a treaty that stipulates the 'globally optimal' abatement plan (as determined by aggregation of benefits and costs across countries), 'even though that is not what is optimal for poor states,' if the treaty can get ratified and survive pressures to cheat (Posner \& Weisbach, 2010, pp. 97-98). They also think it likely that states believing they will be harmed relatively less by climate change will either agree only to limited abatement requirements, or else agree to more demanding requirements only on condition that they receive 'side payments;' and that these payments 'may go from poor to rich, at least in part' (Posner \& Weisbach, 2010, pp. 84-85). Despite objections from perspectives of corrective and distributive justice, Posner and Weisbach would favor such side payments if they were necessary in order to induce the richer countries to agree to a treaty stipulating the globally optimal abatement plan.

\section{Deontology versus Welfarism}

Posner and Weisbach do not contend that their treaty criteria are requirements of justice, and they argue against using requirements of justice as criteria for an acceptable climate treaty. My own view is that a climate treaty should satisfy robust requirements of justice, since it will set the terms for global cooperative mitigation and adaptation efforts that will significantly affect our planet's entire human population, directly and indirectly, from the present into the indefinite future. These cooperative efforts may cause or permit destruction of nations as well as other harms to individual human beings: at stake are fundamental and vital interests of states as well as of the people whom they represent; these interests include survival and security. Therefore the parties to the negotiations (representatives of 
states) should be able to justify their proposals, to each other as well as to the people whom they represent, by reference to a reasonable conception of justice that they all can endorse.

Such a conception would be the focus of an overlapping consensus. ${ }^{13}$ This means that a treaty proposal justified in its terms could be offered in the belief that it is not unjust, and with the reasonable expectation that those to whom it is offered will not find any good reason to reject it as unjust. The parties to the negotiations should offer each other only treaty proposals that are justifiable by reference to such a conception of justice, that is, by appeal to public reason.

The arguments offered by Posner and Weisbach to justify their criteria for a climate treaty are based on a welfarist ethical conception, which is a type of consequentialist theory. Consequentialism refers to a set of ethical theories holding that the rightness or wrongness of acts or policies depend on their consequences. Consequentialist theories are teleological; in ethics, 'teleology' refers to the evaluation of conduct in relation to the end or ends it serves, realizes, or helps to constitute. In this article I use the term 'deontology' to refer to non-teleological conceptions of morality or justice.

A moral framework for the climate treaty negotiations may be either teleological or deontological, depending on the character of the moral principles on which it is based. Consequentialist teleological theories define right conduct or policies as those that produce the outcomes that are best, or that create or increase or promote what is good; first they identify what is good, and from this they derive conclusions about the right thing to do (the best means to the end). Deontological theories are non-consequentialist in the sense that they start with the concepts that are fundamental to morality and justice (such as obligation, duty, voluntary consent, agreement, cooperation, fairness), and on this basis draw conclusions about what outcomes, goals, and interests people may reasonably consider good and how people with different interests can cooperate on fair terms.

Posner and Weisbach do not argue for welfarism, nor do they assume that everyone worldwide endorses it (nor only the members of the academic community, whether worldwide or only in the USA). As they acknowledge, proponents of other conceptions of ethics, morality, and justice, whether religious or secular (which they group together under the term 'deontological approaches') reject consequentialist conceptions including welfarism (Posner \& Weisbach, 2010, p. 8). Furthermore, Posner and Weisbach (2010, p. 173) say that for their purposes they need not make fine-grained distinctions between ethical theories. They use the term 'ethical' to cover social and political justice. I contend that for their purposes it is necessary to distinguish carefully between (a) political conceptions of justice, (b) comprehensive moral doctrines, and (c) partially theorized ethical conceptions such as their own welfarism; it is also necessary carefully to distinguish (as they do not) between (d) Rawls' Law of Peoples, which is a political conception of justice providing principles to guide cooperation among states, and (e) the conceptions of global distributive justice advocated by Rawls' critics, some of whom are self-avowedly anti-statist. ${ }^{14}$

Although they aim to balance 'the cosmopolitan view that people around the globe matter, not just people in one's neighborhood or nation,' with 'the practical realities and benefits of a state system,' and although they acknowledge the existence of nations as 'a basic constraint on ethical arguments,' Posner and Weisbach $(2010$, pp. 6, 173) argue that 'climate change is a problem because it hurts people, not because it hurts countries.' Yet among the many ways climate change may hurt people is that it may damage or destroy economic, social, cultural, and political institutions and practices. According to Rawls, 
utilitarian (including welfarist) arguments for the international as well as domestic legal obligations and rights of states are inadequate (Rawls, 2001, pp. 80-134; 1999, p. 40). Utilitarians acknowledge this inadequacy when they endorse deontological arguments for such obligations, ${ }^{15}$ as do Posner and Weisbach (2010, pp. 178, 182-183) when arguing against free-riding and in favor of the view that states are obligated to cooperate. ${ }^{16}$

According to Posner and Weisbach, a feasible treaty proposal is one that meets the International Paretianism condition. This condition states that all states must believe themselves better off as a result of the climate treaty, 'by their lights' (Posner \& Weisbach, 2010 , p. 6). Many people reject welfarism or, more broadly, consequentialist or teleological comprehensive doctrines about ethics and justice, and instead conceive their state's interests in terms of other secular or religious cultural values. Such people may see little reason to accept Posner and Weisbach's arguments or to agree to treaty proposals justifiable only on welfarist grounds. However, proposals that are justifiable in terms of the public reasons specified by a political conception of justice can be the focus of an overlapping consensus and thus may meet the International Paretianism condition.

Some of the drawbacks of Posner and Weisbach's position emerge from reflection on the presuppositions of the climate treaty negotiations. An analysis of the idea of treaty obligations, sketched in the next subsections, reveals reasons why the parties to the negotiations should offer each other only treaty proposals that are justifiable by public reasons, and why proposals not meeting this criterion are not feasible.

\subsection{Treaty Obligations}

If treaties create binding obligations (in the sense that a state's becoming party to a treaty entitles the other parties to expect that state to comply with the terms of the treaty, despite self-interested reasons to do otherwise, unless it has a legitimate excuse; to object to non-compliance; and to employ appropriate forms and amounts of pressure to ensure compliance or penalize non-compliance), then treaty proposals must meet the condition of being appropriate contents for obligations of that kind. Treaty proposals fail to meet this condition if the addressee of the proposal would not agree to the proposed terms of cooperation (whether due to reasonably regarding them as inconsistent with the point of the cooperation, or inconsistent with their own fundamental interests as they understand them), unless pressured to do so or unless lacking relevant information or comprehension. Treaty proposals can meet the condition only if they do not conflict with states' fundamental interests, but instead serve their common good.

\subsection{The Common Good}

If states regard cooperation structured by a treaty as necessary for securing or furthering their own fundamental interests, then all states cooperating for this reason can share a common good, namely, the furthering of their respective fundamental interests by means of the treaty. Treaty proposals can serve this common good only if the addressees can accept them as binding, and parties to treaty negotiations cannot accept a treaty proposal as binding if it conflicts with the point of the cooperation, which is to serve their common good (including the fundamental interests of each and every state). Justifications offered in terms of public reasons should be acceptable to all parties willing to cooperate on fair terms. 


\subsection{Public Reasons}

Parties willing to cooperate on fair terms aim to avoid offering proposals that (a) can reasonably be rejected by the addressee due to conflict with its fundamental interests or with the common good, or that (b) would undermine the addressee's ability, or conflict with its rights, to participate in the cooperation (in this case, to participate in the negotiations and sign a treaty); or that (c) cannot be justified as serving the common good except by presupposing the truth of a comprehensive doctrine that is controversial among the parties. This three-part condition can be met by proposals justifiable in terms of a political conception of international justice endorsable by all of the parties in common. Such a conception can be developed by analyzing the idea of legitimately governed states cooperating fairly, as does Rawls: his Law of Peoples provides a moral basis for the rights and obligations of states, including their obligations to secure the basic human rights recognized in international law. Posner and Weisbach neither offer nor cite any welfarist or other utilitarian conception of these rights and obligations, and any such conception would be problematic, for reasons corresponding to the distinctive theoretical and practical advantages of a political conception of climate justice, as I indicate below.

\section{A Political Conception of Climate Justice}

The political conception of climate justice here proposed endorses the principles of Rawls' Law of Peoples, emphasizes climate-change-relevant implications of some of them, and adds a principle for determining fair shares of climate-treaty-related benefits and burdens. In The Law of Peoples, Rawls (1999, p.37) proposes eight principles as specifying the fundamental rights and duties of decent political societies, which he calls 'peoples' (as distinct from 'states,' which refers to states that do not meet the criteria of decency). ${ }^{17}$ The principles of the Law of Peoples are the following:

(1) Peoples are free and independent, and their freedom and independence are to be respected by other peoples.

(2) Peoples are to observe treaties and undertakings.

(3) Peoples are equal and are parties to the agreements that bind them.

(4) Peoples are to observe a duty of non-intervention.

(5) Peoples have the right of self-defense but no right to instigate war for reasons other than self-defense.

(6) Peoples are to honor human rights.

(7) Peoples are to observe certain specified restrictions in the conduct of war.

(8) Peoples have a duty to assist other peoples living under unfavorable conditions that prevent their having a just or decent political and social regime.

These principles establish equality among peoples by ascribing the same fundamental rights and duties to them all. Rawls contends that the eight principles, if interpreted in the way he advocates, are fair to all peoples, and that they, together with his criteria for a decent society and his list of basic human rights, provide appropriate content for the foundation charter of a reasonably just system of international law. 
The Law of Peoples focuses mainly on questions concerning basic human rights in relation to the moral basis, content, and limits of the rights of peoples. It provides rationales for the limitation of both a state's right to wage war and a state's right of internal sovereignty, as found in international law since World War II. Rawls' overarching goal is a world in which ethnic hatreds leading to nationalistic wars will have ceased (Rawls, 1999, pp. 6-7).

Participants in fair cooperation must, logically, be agents that are both capable of cooperating on fair terms and motivated to do so. If there can be a just international order, then it must be possible for states to have such a capacity and such a motivation, which means that it must be possible for them to be reasonable as well as rational agents. Any state meeting Rawls' criteria for decency (that is, any political society that is legitimately governed and non-expansionist, i.e., any people, as Rawls understands 'people') can be such an agent. It is possible for political societies to meet the criteria of decency; some present and past societies have met them. And it is plausible that, under certain realistically possible conditions, societies meeting these criteria would tend to act reasonably, as Rawls argues in the Law of Peoples (1999, pp. 25-30, 124-127).

The eight principles of the Law of Peoples are fair in the sense that decent societies regarding themselves and each other as free and equal, behind a veil of ignorance, ${ }^{18}$ would not have any reason to reject them. ${ }^{19}$ As regards freedom, if a political society is capable of acting for reasons, then it is free in a certain sense. If it is independent, then it is free in another sense: it is not obligated to obey any other political society. If it makes and follows its own laws and policies, then it is free in a further sense: it is self-determining. As Rawls conceives peoples, they are political societies that are both capable of acting for reasons (as understood above) and independent. His position, which I endorse, is that self-determination, duly constrained by appropriate conditions, is an important good for a people, and that international law should not ascribe to peoples unlimited rights of self-determination and independence.

Rawls assumes that all peoples have an interest in receiving from all other peoples a proper respect and recognition of their equality. Here, equality means equality of status as peoples entitled to the same rights as other peoples under international law. Rawls thinks that when seeking fair principles, it is appropriate to start from a baseline of equality in this sense. He argues that no utilitarian principle would be preferred by peoples (i.e., the trustees representing them) behind the veil of ignorance, since none would be prepared to count, as a first principle, the benefits for another people as outweighing the hardships imposed on itself. The trustee of each people, i.e., the party representing it in the original position, ${ }^{20}$ will aim to preserve their society's equality and independence; and by insisting on equality among peoples, these trustees rule out any form of the principle of utility. Whatever rights peoples are to have in relation to each other, these rights must be the same for them all, and must be secure: they must not be contingent in the ways that rights grounded in a utilitarian conception of justice would be contingent (Rawls, 1999, p. 40). I endorse this argument, and I agree with Rawls that justice restricts permissible means for promoting good consequences.

Parties to treaty negotiations are obligated to respect basic human rights. Any legitimately governed society undertakes to secure at least certain basic rights for all of the individual human beings under its government. Human rights would be secured universally if all states became decent political societies, i.e., peoples, and if all decent societies formed an association and together followed the Law of Peoples, thus constituting what Rawls 
calls a 'Society of Peoples.' A Society of Peoples can include peoples that are not liberal democracies, partly because the list of basic human rights appropriate for the foundation charter of a Society of Peoples does not include all of the basic rights of citizens of liberal democracies. ${ }^{21}$ The basic human rights can be justified either as belonging to a liberal political conception of justice (as a proper subset of the rights and liberties secured to all free and equal citizens) or as belonging to a conception of a well-ordered associationist society. ${ }^{22}$ They can be affirmed by all, not only by liberals or Westerners; as Rawls says, the basic human rights are not 'politically parochial' (Rawls, 1999, p. 65). ${ }^{23}$

Some of the concerns of non-Annex I countries ${ }^{24}$ (for example, that the UNFCCC be observed, and that the principle of CBDR be followed, and that parties to treaties be recognized as having equal standing under international law) can be expressed in terms of principles \#1-3 of the Law of Peoples, others in terms of principles \#6 and \#8. From these principles one can draw implications regarding access to resources to fulfill basic human needs (including global climatic conditions necessary for the possibility of fulfillment of these needs). Societies may lack the means to meet the criteria of decency; such 'burdened societies' may lack material and/or technological resources, human capital and know-how, and/or the requisite political culture (Rawls, 1999, pp. 90, 105-113). Clearly, climate change may worsen conditions in some burdened societies, and may cause some previously decent societies to become unable to fulfill their people's human rights. ${ }^{25} \mathrm{~A}$ climate treaty must aim to ensure the material preconditions necessary so that all societies may meet the criteria of decency. Every state must, if it is able, take at least the steps such that not taking them would be inconsistent with being committed to this aim. Beyond this, states should each bear their fair share of the costs of the necessary climate change mitigation and adaptation measures. ${ }^{26}$

\section{Practical Implications of the Political Conception of Climate Justice}

If all parties to the climate treaty negotiations were to acknowledge and respect the basic moral constraints set by the political conception of climate justice, this would reduce their conflicts and make it easier for them to agree about which policy proposals would assign fair shares of the costs and other burdens involved in the necessary measures for reduction of greenhouse gas emissions and adaptation to climate change. Below I offer some general guidelines for evaluating climate change treaty proposals in accordance with these basic moral constraints. Then I consider how the concerns of all sides to the disputes about CBDR (common but differentiated responsibilities) can be expressed in terms of, or in relation to, the political conception of climate justice, and how it can help lead to reconciliation and agreement on a treaty.

State representatives should ask the following questions when evaluating treaty proposals:

(1) Would the proposal be consistent with the eight principles of the Law of Peoples (or with a justified qualification of one or more of its principles)?

(2) Would the proposal...

$$
\text { (2.1) ... allow progress toward a Society of Peoples, or }
$$




\section{(2.2) ... increase the likelihood of it or open up more ways to it?}

In general, when deliberating about what the content of a treaty should be, it is necessary to identify the relevant morally required and permissible goal(s) and the morally permissible means to them, and then to consider which of these means would be most effective and efficient as well as politically feasible in the current situation. ${ }^{27}$ In relation to climate change, one morally required goal is to prevent global average temperature from rising to the point of causing inundation of the territories of island nations and sea-level coastal nations, since no party to the negotiations whose country would be devastated under higher global average temperatures can agree to measures allowing this; to do so would conflict with the commitment to secure the human rights of the country's people, and also would conflict with recognition of the country's status as a party to the negotiations entitled to equal rights under international law. ${ }^{28}$

If it is not possible (given the limited time available, and given the political realities), ${ }^{29}$ to bring all of the parties to agree on the morally required goal, then there is no choice but to agree on a goal that comes as close as possible in the current situation to the morally required goal. Setting the less satisfactory goal (perhaps 2 degrees Centigrade) in the climate treaty might be necessary for securing conditions that may permit achieving the more satisfactory goal (perhaps 1.5 degrees Centigrade) by other means, including policies that can be implemented at various levels of government or by nongovernmental organizations, commercial corporations, and individuals. There may be various morally permissible means to the agreed goal that could be sufficiently effective and efficient. Morally permissible means would involve fair distribution of the benefits and burdens associated with mitigating and adapting to climate change, ${ }^{30}$ the means chosen must be as fair as possible in the current situation.

Legitimate concerns of negotiating parties can be articulated either in the terms provided by the political conception of climate justice or consistently with it. All negotiating parties should use this framework for determining appropriately justified answers to the questions at issue. Consider first the concerns voiced by the US representative to the UNFCCC.

According to US Envoy Stern, ${ }^{31}$ all countries have 'common responsibilities in regard to climate change,' but 'what we need to do must be differentiated according to our own circumstances and capabilities.' The two 1992 categories-Annex I (developed countries) and Non-Annex I (developing countries)—were originally distinguished on the basis of countries' material circumstances, which have changed in the intervening years, dramatically in some cases; therefore 'once we have made sure that the material interests ... of developing countries are fully protected ... then there is no justification' for using the 1992 categories. To do so in an agreement that will take effect nearly three decades after 1992 and will govern climate diplomacy in future decades 'would be inimical to ambition and would undermine the political cohesion we need to build an effective and durable climate system going forward.' Stern rejects the idea that the 1992 categorization of countries was based on their pre-1992 historical responsibility and was intended to remain so based, and implicitly argues that, given constantly changing circumstances, such a basis for the categorization would have been neither fair nor wise. ${ }^{32}$

The Lima agreement says that the 2015 treaty should reflect 'the principle of common but differentiated responsibilities and respective capabilities, in light of different national 
circumstances.' This wording differs slightly from the wording in the UNFCCC. During the Lima negotiations, many participants argued that the developed countries must acknowledge their disproportionate historical and moral responsibility for causing climate change as well as for persisting deep inequalities due to past colonization; and that omission of the phrase 'differentiated responsibilities' from the text of the agreement would erode the mutual trust and confidence necessary for successful cooperation in responding to climate change. ${ }^{33}$

My view is that justice requires powerful states to refrain from unreasonably hard bargaining. It also requires that countries conceive their national interests not merely in terms of minimizing economic costs to themselves and increasing or preserving their own power, but also in terms of building the kinds of mutually respectful, trusting relationships necessary for cooperation to achieve a stably peaceful and just international order. Voluntary cooperation on the basis of mutually acknowledged commitment to shared goals and principles is required because respect for national sovereignty precludes proceeding otherwise. Differentiation (CBDR) should be retained, but with qualifications acknowledging countries' changed material circumstances, on condition that the material interests of poorer countries (at least those necessary for fulfilling the basic human rights of their populations) be fully protected. When considering whether to preserve the 1992 categorization of countries, ${ }^{34}$ the negotiators should consider what principle to guide judgment regarding cases of this kind ${ }^{35}$ they would endorse if they were behind a veil of ignorance depriving them of knowledge of which country they represent.

\section{Fair Shares}

The climate treaty negotiators should aim to ensure the material and other preconditions for the independence, self-determination, and stability of legitimately governed states, so that they can secure at least the basic human rights. Every state must, if it is able, take at least the steps such that not taking them would be inconsistent with being committed to the aim of ensuring the material preconditions necessary so that all societies may meet the criteria of decency. Beyond this, states should each bear their fair share of the costs of the necessary mitigation and adaptation measures. ${ }^{36}$

A number of alternative approaches to determining fair shares of climate-treaty-related benefits and burdens have been developed in the academic literature. Four of the most prominent approaches can be combined and revised so as to yield a principle that is compatible with the political conception of climate justice. Here I present this fair-shares principle, and in the next section I apply it to two policy proposals. Within the space constraints of this article I cannot fully discuss or defend this principle. My aim here is merely to indicate how the political conception of climate justice can be developed so as to guide and constrain policy deliberations.

According to the approach taken by sufficientarians, since distributive justice gives every person a claim to a sufficient quantity of certain goods to provide for basic needs, a climate treaty should impose no sacrifice on the indigent. According to the prioritarian view that progressivity is a requirement of distributive justice, the less well off one is, the less one should be required to contribute to the production of any given good, so the wealthy should contribute more than the poor to the mitigation of global warming. There are various versions of both the sufficientarian view (to which I will refer as the 
'sufficiency principle') and the prioritarian view (to which I will refer as the 'priority principle'); for present purposes I will use a version of the priority principle formulated by Derek Parfit and a version of the sufficiency principle formulated by Robert Huseby (2010). Parfit distinguishes the idea that equality is to be valued and sought for its own sake, as intrinsically valuable, from the priority principle, which he formulates as follows: 'Benefiting people matters more the worse off these people are. ${ }^{37}$ According to Huseby,

It is, in itself, bad if a person is not sufficiently well off. It is worse the farther from a sufficient level a person is (and especially bad if a person's basic needs are unmet), and worse the more people that are not sufficiently well off. (Huseby, 2010, p. 180)

Huseby favors regarding the means to subsistence or the satisfaction of basic human needs as a minimal sufficiency threshold ('insufficiency below subsistence level is morally more urgent than insufficiency above it'), and argues for the following maximal threshold: 'people are sufficiently well off if their welfare level gives them a reasonable chance of being content' (Huseby, 2010, p. 182). He argues that we should give absolute priority to those below the maximal sufficiency threshold (over those above it), and as regards those below this threshold, we should prioritize between them by taking into account 'both how many people can be benefited, and how far from the threshold these people are;' those below the minimum threshold should be given special concern and strong priority (Huseby, 2010, pp. 184-185). ${ }^{38}$

According to a human rights perspective developed in the academic literature, the greenhouse-gas-absorptive capacity of the atmosphere is something to which each human being has an equal right. ${ }^{39}$ Insofar as any human rights perspective is grounded in arguments that are neutral between deontological and teleological justifications of human rights, it may avoid conflict with the Law of Peoples and the political conception of climate justice. ${ }^{40}$ Simon Caney (2010, p. 165) presents his human-rights-centered analysis of the impacts of climate change as grounded in arguments that are neutral in this sense. ${ }^{41}$

According to the due care approach advocated by Richard W. Miller, climate policymakers should ensure fairness by employing a Rawlsian veil of ignorance. Miller emphasizes both that all who emit greenhouse gases must undertake to mitigate the harmful side-effects that they jointly create, and that those who consider adopting mitigation and/ or adaptation policies must take into account the harmful side-effects, such as thwarted opportunities, that may result from these policies. Fair burden allocation would, he contends, 'give priority to the gravest combined burdens of climate danger and climate mitigation that people suffer, to grave burdens that more people suffer and to grave burdens that are readily relieved' (Miller, 2010, p. 105). In order to facilitate impartial deliberation about particular policies, policymakers and negotiators should utilize a Rawlsian veil of ignorance (Miller, 2010, pp. 33, 74). ${ }^{42}$ As I interpret Miller's proposal, the policymaker's job would be to promote human welfare (construed in terms of human rights and their preconditions, as understood within the framework of the Law of Peoples) by considering, behind a veil of ignorance, how any proposed policies compare to each other on Miller's first two criteria: (1) the gravest combined burdens of climate danger and climate mitigation that people suffer, and (2) grave burdens that more people suffer. If the policies seem equally bad, then the choice is to be made by applying the third criterion (grave burdens that are readily relieved). 
Miller's proposal can be combined with a revised form of Huseby's sufficiency principle (which includes a limited priority principle). I will refer to this combination as the Huseby-Miller principle. Huseby (2010, pp. 185-186) emphasizes the compatibility between his principle of sufficiency and the view that people should be treated with equal respect and concern. He holds that the moral equality between persons justifies 'equal rights and liberties, (formal) equality of opportunity, access to health care etc.,' and that the principle of sufficiency requires such 'background conditions' (Huseby, 2010, p. 186). The Law of Peoples does not rely on equally strong assumptions, ${ }^{43}$ but a weaker form of Huseby's sufficiency principle ${ }^{44}$ would be consistent with the Law of Peoples. So would a priority principle limited by incorporation into the revised form of Huseby's sufficiency view.

\section{Evaluation of Policy Proposals: Two Examples}

Huq and Richards (2014) have proposed a global fossil fuel extraction levy to pay for loss and damage from climate change. ${ }^{45}$ They write that although 'such a levy makes perfect legal and moral sense,' there are 'technical issues to be ironed out,' and a key challenge is 'how to have a globally-applied levy take into account the equity principle of common but differentiated responsibilities and respective capabilities at the heart of the UNFCCC.' One way to do so, they suggest, is to establish a process allowing less-developed countries to apply for permission to opt out of contributing the levy to the international loss and damage mechanism so that they can instead use it for domestic mitigation or adaptation. This forward-looking proposal has several advantages from the perspective of the Huseby-Miller principle. Negotiating parties guiding their deliberative reasoning by asking the questions required by this principle might well opt for such a proposal, unless a better one were available. This comparative judgment would have to take into account the probable consequences of this proposed policy when implemented in the context of other policies in the actual circumstances. ${ }^{46}$

Paula Casal (2012, pp. 419-433) contends that an extraction-only tax would impose greater costs on the least fortunate than her proposed alternative, namely, global progressive environmental taxation (see also Casal, 2011a, pp. 307-327, 2011b, pp. 353-365). She advocates 'starting with oil use' and then broadening the tax base by taxing either use or ownership of a wide range of resources, depending on the consequences (for pollution reduction and poverty reduction) of either type of resource taxation (Casal, 2011b, pp. 357-358, 358; see also 2011a, pp. 320, 323, 327). Casal's proposal for global progressive environmental taxation has features that are attractive from the perspective of the Huseby-Miller principle. However, her proposal addresses two large categories of problem, pollution and poverty, and is not tailored to solve the narrower problem of how best (for purposes of agreement on a climate treaty in December 2015) to determine fair shares of the costs of implementing the necessary mitigation and adaptation policies. While she may be right that parties in a Rawlsian original position (which she construes, as does Thomas Pogge, as representing all of the individuals in the world, not as representing peoples) would be less likely to endorse an extraction-only tax, despite the possibility of later compensation for the less fortunate, and would be more likely to endorse a broader tax base that 'spreads the bets and lowers the risks' (Casal, 2011b, p. 359), this argument does not fit comfortably into the framework of the political conception of climate justice. This argument also leaves open the questions of (a) whether this type of tax on global resources 
must be included in the 2015 climate treaty, or could be implemented independently of it or on the basis of it (World Resources Forum, 2013), and (b) whether parties representing peoples behind a veil of ignorance would (or the actual parties to the current climate negotiations should) endorse such a proposal over an alternative according to which countries determine their own voluntary contributions to a Green Climate Fund to be used for financing the implementation of mitigation and adaptation policies worldwide. ${ }^{47}$

\section{Corrective Justice and the Climate Treaty Negotiations}

A conception of corrective justice must be backward-looking, unlike the political conception of climate justice. US Envoy Stern advocates a forward-looking climate treaty, and Posner and Weisbach likewise oppose using backward-looking principles of justice to design a climate treaty. They emphasize the urgent importance of reaching agreement on a climate treaty by December of 2015 ; for this reason, they contend, the negotiators should not undertake to achieve corrective justice by means of the treaty. They doubt that there remains enough time to settle the controversies by arriving at answers to the difficult philosophical as well as legal questions about the assignment of individual and collective moral responsibility, as well as about appropriate penalties, that are raised by the demands for corrective justice. ${ }^{48}$ And they point out that it would be an ironic and momentous tragedy if efforts to achieve corrective justice, made on behalf of poorer and more vulnerable countries, derailed the climate negotiations, thus bringing about (by obstructing efforts to prevent) great harm to these countries.

In arguing that the climate treaty should comply with the (forward-looking) political conception of climate justice, I am not rejecting any requirements of corrective justice for which others have argued. ${ }^{49}$ The political conception of climate justice provides support for some claims of corrective justice. Moreover, fulfillment of the requirements of the former would in effect fulfill requirements of the latter to a significant extent. By endorsing the political conception of climate justice, states would acknowledge (at least implicitly) that much international conduct has been gravely unjust, egregiously violating the principles of the Law of Peoples. Fulfillment of the duty of assistance specified in the Law of Peoples would greatly improve conditions in countries that have been subjected to unjust invasions or colonialist or imperialist exploitation.

While I agree with Posner and Weisbach about the urgent importance of achieving a climate agreement by December, I contend that the primary objective must be to achieve, as soon as possible, a climate treaty that satisfies the requirements of the political conception of climate justice to the extent possible within the relevant time-frame. To achieve such a treaty would be to secure essential preconditions for a just global Society of Peoples, as well as preconditions for achievement of the goals of sufficientarian, prioritarian and egalitarian advocates of distributive justice (in the narrow sense of this term).

\section{Distributive Justice}

Posner and Weisbach (2010, p. 76) provide only a vague and ambiguous description of a Rawlsian conception of distributive justice, which they criticize. ${ }^{50}$ The description applies equally well to the positions taken by some of Rawls' critics, in particular, Charles Beitz 
and Thomas Pogge. For this reason the criticisms that Posner and Weisbach direct toward Rawls fail to apply to his own view.

Nowhere in their book do Posner and Weisbach cite either Rawls' 1993 article on the Law of Peoples or his 1999 book. ${ }^{51}$ Moreover, they use the term 'distributive justice' to refer only to equalization of material conditions, whether done for the sake of increasing aggregate welfare or for other reasons. ${ }^{52}$ This is the way the term is used by some of Rawls' most prominent critics. To think that this is the only meaning of 'distributive justice' is to overlook the difference between the broader and narrower senses of the term that Rawls distinguishes (Rawls, 2001, pp. 42, 122). In the narrower sense, only questions of distribution of wealth and income ${ }^{53}$ are questions of distributive justice (Rawls, 2001, pp. 42, 122). In the broader sense, both (a) the question of which principles should guide creation and reform of the basic institutions (legal and political as well as economic) of a single society, and (b) the question of which principles should guide creation and reform of international laws and institutions, are questions of distributive justice. If one thinks that all questions of justice that concern laws and political, social, and economic institutions must be either questions of distributive justice in the narrow sense or else questions of corrective justice (concerning rectification of past wrongs or crimes), then one is missing a large category of important questions about justice. These include many questions about the rule of law and basic rights that are among the fundamental questions of distributive justice addressed in the Law of Peoples.

\section{Conclusion}

Above I have argued that Posner and Weisbach's welfarist approach to climate treaty negotiation has theoretical, moral, and practical drawbacks, while the political conception of climate justice has corresponding advantages and is an appropriate framework for the climate treaty negotiations. ${ }^{54}$ Since this conception of climate justice is based on the Law of Peoples, which is a political conception of international justice and human rights that can be the focus of an overlapping consensus, and since the proposed fair-shares principle is consistent with the Law of Peoples and endorsable by proponents of several of the main approaches to determining fair shares, there is reason to think that the political conception of climate justice can, like the Law of Peoples, serve as a basis for international cooperation freely undertaken, willingly continued, and long-enduring despite the great cultural and political differences between countries.

This is not true of the welfarist approach advocated by Posner and Weisbach. They declare that for their purposes they can 'bracket the largest debates' between deontological conceptions of justice and other conceptions such as their own welfarism, and that their position is 'broadly compatible with most deontological claims' (Posner \& Weisbach, 2010, p. 172). However, in giving short shrift to deontological conceptions of justice and offering little discussion or defense of welfarism (their own definition of which is brief and vague), ${ }^{55}$ Posner and Weisbach neglect to distinguish between the Law of Peoples and the positions taken by its critics, cannot see the great value of Rawls' political conception of international justice, and do not notice that the arrows of criticism they themselves aim at the Law of Peoples do not reach their intended target. Therefore they fail to consider the need for a political conception of climate justice on which there can be an overlapping consensus. 
Today the United States and most, if not all, other states acknowledge constraints of justice applying to international relations, even though they disagree about what distributive justice may require as regards redistribution of wealth. These states must, on pain of logical inconsistency, acknowledge the implications of the principles of international justice that they already (purportedly) endorse; otherwise they would not actually endorse them. These implications include:

- Commitment to international peace and the rule of international law.

- Commitment to refrain from acting in ways that would render impossible, or would obstruct, the development of a peaceful global order of legitimate states freely cooperating in accord with international law.

- Commitment to contribute to efforts to prevent states from losing the material preconditions for fulfilling the basic human rights of their populations and sustaining legitimate political institutions.

These implications set a condition for an acceptable climate treaty: it must be possible for negotiators to propose it to each other, and to accept it freely, consistently with the above commitments. A treaty negotiated within the framework of the political conception of climate justice would meet this condition, but a welfarist treaty of the kind advocated by Posner and Weisbach would not.

Humanity can no longer take for granted that the natural ecological and climate systems on which our lives depend will continue to function as they did throughout history prior to the era of industrial economies reliant on fossil fuels (indeed, these systems have already changed dramatically, as is widely known although not universally admitted). The crisis of climate change is clear, and we need a moral framework for dealing with it: one that can help us to find common ground, build mutual trust and confidence, create enduring structures for cooperation, and make progress toward the goal of a stably peaceful and just international order that facilitates sustainable development. ${ }^{56}$ The political conception of climate justice offered above is such a framework.

\section{Acknowledgements}

I delivered a precursor of this article ('Climate Change and Global Justice: A Critique of V. Zanetti, E. Posner, and D. Weisbach') at the Georgia State University conference, Global Justice and International Law, September 2012. I thank Andrew Altman, Jean-Cassien Billet, Ruediger Bittner, Gillian Brock, Martin Carrier, Francis Cheneval, Candice Delmas, Frank Dietrich, Christie Hartley, Kristen Hessler, Maria Kronfeldner, Lukas Meyer, Richard W. Miller, Thomas Pogge, George Rainbolt, Anna Stilz, Kok-Chor Tan, Adam Toon, and Veronique Zanetti for comments or discussions of topics relating to that paper. For especially valuable written comments on this article, I thank Jeppe von Platz and Allen W. Wood (both of whom commented on more than one draft), and for helpful written comments on a draft I thank also Austin Babrow, Samuel Freeman Alfred Lent, Elijah Millgram, and two anonymous reviewers for this journal. I am grateful to Stela Goldenstein, former Secretary of the Environment of São Paulo, Brazil, for correspondence regarding the position taken by U.S. Envoy Stern. For all of their work as the guest editors of this special journal issue, I thank Idil Boran and Kenneth Shockley. I am especially grateful to my husband, Todd Shannon Bastin, for helping me think through my arguments for this paper and helping enable me to write it (sine quo non). 


\section{Disclosure statement}

\section{No potential conflict of interest was reported by the author.}

${ }^{1}$ An 'optimal' climate treaty 'reduces emissions to the extent that the cost of reducing emissions a little bit more is equal to the benefit of reducing emissions a little bit more; in economic terms, the marginal costs equal the marginal benefits,' taking into consideration the lowest cost emissions reductions wherever they may be worldwide and counting 'all of the harms from climate change' (Posner \& Weisbach, 2010, p. 56).

${ }^{2}$ More recently Posner and Weisbach have reaffirmed their central contention. They argue that a feasible climate treaty would be 'designed so that all states consider themselves better off than in the status quo,' and that achieving such a treaty in the near future requires focusing on how to 'reduce carbon emissions at an acceptable cost,' since '[e]ven if Americans were to take seriously the ethical arguments of philosophers, it seems unlikely that many of them would be persuaded that a climate treaty should impose disproportionate burdens on the US, and likewise for people in other rich countries' (Posner \& Weisbach, 2013, pp. 355, 358).

${ }^{3}$ Posner and Weisbach's welfarism is a conception of the fundamental ethical considerations that should guide policymaking, according to which policymakers should aim to maximize welfare or well-being: 'Welfarists seek policies that maximize people's well-being, defined variously as their subjective sense of well-being, satisfaction of desires or preferences, or satisfaction of certain objective parameters' (Posner \& Weisbach, 2010, p. 171). Posner and Weisbach (2010, p. 8) neither specify a particular interpretation of welfare nor exclude non-humans: 'The welfarist approach approves of acts that increase the welfare of relevant people (and possibly animals)'. Posner and Weisbach (2010, p. 217, n. 7) say that utilitarianism is a form of welfarism; however, as these terms are normally used, welfarism is a form of utilitarianism.

${ }^{4}$ While agreeing with Posner and Weisbach about the need for a climate treaty, I agree also with Dale Jamieson: 'Most action on climate change will take place within regions, within countries, within communities, and in the hearts and minds of individuals' (Gutting \& Jamieson, 2015).

${ }^{5}$ John Broome (see Broome, 2012), too, takes a welfarist approach to questions of justice and ethics in relation to climate change. However, his particular arguments differ from those offered by Posner and Weisbach.

${ }^{6}$ In this article I focus on the topic of distributive justice, but later I briefly return to the topic of corrective justice.

${ }^{7}$ Much of the academic work on global justice published in the last several decades has engaged with the central ideas of John Rawls' conceptions of domestic and international justice.

${ }^{8}$ My interpretation of Rousseau is informed by the work of Joshua Cohen (see Cohen, 2010) as well as the work of John Rawls (see Rawls, 2007b). My interpretation of Kant's political philosophy is presented in Bernstein, 2008a, 2009, 2013, 2014.

${ }^{9}$ Although in this article I will refer to this conception as 'the political conception of climate justice,' I do so only for convenience (instead of using the longer phrase, 'a political conception of justice appropriate to serve as a moral framework for the climate treaty negotiations'). I claim neither that it is the sole possible formulation of a reasonable political conception of climate justice nor that all questions of climate justice can be adequately addressed by it.

${ }^{10}$ This and all quotations of Stern are from Stern, 2014. 
11 'According to corrective justice, if one person harms another person, the first person should provide a remedy, such as cash, to the victim' (Posner \& Weisbach, 2010, p. 100).

${ }^{12}$ According to Posner and Weisbach (2010, pp. 96-98), distributive justice requires reducing poverty and giving priority to the poorest and most desperately needy.

${ }^{13}$ For discussion of the idea of an overlapping consensus, see Rawls (1993/1996/2005, pp. 133-172; 1999, pp. 32, 172-174; 2001, pp. 32-38).

${ }^{14}$ Among the most prominent critics of Rawls' Law of Peoples are Charles Beitz, Martha Nussbaum, Onora O'Neill, and Thomas Pogge. For an explanations and rebuttals of their criticisms, see Bernstein\# 2007a2012c2012d2012e2012f2012g2012h.

${ }^{15}$ Compare Rawls' analysis of the political philosophy of John Stuart Mill: see Rawls, 2007a, pp. 307-308, 313.

${ }^{16}$ In economics, free riders either consume more than their fair share of a common resource, or pay less than their fair share of the cost of a common resource; in relation to public goods more generally, free riders benefit without doing their fair share to generate or maintain the good.

${ }^{17}$ Rawls discusses the idea of a people in Rawls, 1999, pp. 4, 17, 25-27, 34-37, 44-45, 111-113.

${ }^{18}$ Rawls discusses the idea of the veil of ignorance in Rawls, 1999, pp. 30-33, 43, as well as in Rawls, 1993/1996/2005, pp. 24-27

${ }^{19} \mathrm{I}$ explain the argument justifying the eight principles in Bernstein, 2012g.

${ }^{20}$ Rawls explains the idea of the original position with its veil of ignorance in Rawls, 1999, pp. 10, 17, 26, 30-33, 39-42, 63, 68-70, 82-83, 115, 140, as well as in Rawls, 1993/1996/2005, pp. 304-310. The original position is a theoretical device used in a type of thought experiment for testing the fairness of principles for organizing political and economic cooperation. Different versions of the original position (and of the veil of ignorance) are appropriate for answering different moral and political questions. In the Law of Peoples Rawls uses a version of the original position in order to test proposed principles of international justice. He characterizes it by various stipulations. For example, each of the parties in the original position is responsible for the fundamental interests of a decent society (either liberal or not), and they are behind a veil of ignorance that deprives the parties of knowledge of any particulars about their society, such as the size of its territory, its level of economic development, its natural resources, its population, or how powerful it is as compared to other societies. The principles that would be chosen unanimously by these parties behind the veil of ignorance would serve the fundamental interests of every people and would secure basic human rights globally if all peoples were to establish a Society of Peoples based on these principles.

${ }^{21}$ See Bernstein, 2006, $2007 b$.

${ }^{22}$ An associationist form of society 'sees persons first as members of groups—associations, corporations, and estates' (Rawls, 1999, p. 68).

${ }^{23}$ Moreover, they 'do not depend on any particular comprehensive religious doctrine or philosophical doctrine of human nature' (Rawls, 1999, p. 68).

${ }^{24}$ Regarding the categorization of countries, the UNFCCC implements the concept of CBDR by creating several classes of parties through the annexes. Annex I includes the wealthier OECD (Organization for Economic Cooperation and Development) States, as well as the former Eastern Bloc States 'undergoing the process of transition to a market economy.' Annex II includes only the OECD States. 'By omission, therefore, all remaining parties are developing countries. At several junctures ... the UNFCCC 
makes further special provisions for "least developed countries" and "small island States"” (Guruswamy, 1997/2012, p. 225).

${ }^{25}$ See Intergovernmental Panel on Climate Change, 2014.

${ }^{26}$ Again, what states' representatives in the climate treaty negotiations can reasonably and plausibly commit their state to do may depend on their state population's political will and on realistic expectations about the likelihood of reshaping it to a sufficient extent within the time available.

${ }^{27}$ To change current conditions so as to approach more closely the ideal of the Society of Peoples would require not only that burdened societies be assisted (and perhaps also compensated), but also that other states failing to meet the criteria of decency (e.g., those with oppressive governments) be reformed. Significant changes such as these are not likely to happen in time for the climate treaty meeting scheduled for December of 2015. The most that could be done is to take certain initial necessary steps toward making such changes. Does the climate treaty negotiation provide a uniquely valuable opportunity for some countries to ensure that such steps get taken by other countries? If some countries believe that it does, then they may refuse to agree to a climate treaty unless other countries take such steps; but if the other countries refuse to take such steps, then it may be impossible to reach agreement on a climate treaty. In order to avoid this outcome, the negotiators should interpret and use the above questions with these contingencies in mind.

${ }^{28}$ On this topic, Sovacool et al. misinterpret Rawls. See their remarks about Tuvalu in Sovacool, Sidortsov, and Jones, 2014, p. 34.

${ }^{29}$ Suppose a country's representative claims that it is significantly unlikely that her country's population or legislature would accept a climate treaty incorporating a requirement of justice grounded in the Law of Peoples, and there is sufficient evidence supporting this claim. In this case it would be necessary to aim for an agreement that would approach fulfillment of the relevant requirement of justice as closely as possible (given the current contingent constraints) and would leave open, or would open up, a way to fulfill that requirement of justice more completely in the future.

${ }^{30}$ Below I discuss fair shares of costs and other burdens.

${ }^{31}$ As above, all quotations of Stern are from Stern, 2014.

32 'China is not just the largest emitter of greenhouse gases, it is the second largest historic emitter. Nearly every decade, the world emits more than all the CO2 we emitted before 1970. A number of non-Annex 1 countries are at this point among the world's wealthiest. Dozens have higher per capita income than the low end of Annex 1 countries' (Stern, 2014).

${ }^{33}$ See, e.g., Priest, 2014, and Embajada de Brasil, 2014.

${ }^{34}$ A reason to doubt that the 1992 categorization of countries was based on their pre-1992 historical responsibility, and was intended to remain so based, is provided by the summary of the UNFCCC's remedial objectives offered in Guruswamy, 1997/2012, p. 222: '[The third remedial objective is that] climate change policies and laws should be based on equity and in accordance with the principle of CBDR [art. 3(1)]. This principle recognizes that only international cooperation will help to resolve a problem of the magnitude of climate change, but that in responding to the problem different states have different social and economic conditions that affect their response capabilities. CBDR also incorporates the equitable notion that industrialized countries, which have [notice the tense of this verb] the largest share of historical emissions of GHGs, should take the first actions to ameliorate the problem. It deserves emphasis, however, that in the UNFCCC developing countries accepted their "common" responsibility for addressing climate change. The UNFCCC refers to the CBDR of all States, and does not define such responsibilities as the sole and exclusive obligation of industrialized countries.' 
${ }^{35}$ The question is whether treaty negotiators who have the authority to change a previously agreed legal categorization should preserve it, despite relevant circumstances having changed so as to render the previous categorization unwise in terms of efficiency.

${ }^{36}$ What states' representatives can reasonably and plausibly commit their state to do may depend on their state population's political will and on realistic expectations about the likelihood of reshaping it to a sufficient extent within the time available.

${ }^{37}$ Huseby is my source for Parfit's version of the priority principle: Huseby, 2010, p. 185, quoting from p. 213 of Parfit, 1997. Regarding sufficiency, Huseby (2010, p. 179) explains that it is 'a telic principle (i.e., one directed toward an end or ideal) according to which we can evaluate outcomes based on a limited amount of information concerning especially the number of individuals and their welfare levels.' He formulates the principle as he does in order to evade an objection (raised by Paula Casal): that defenders of the sufficiency principle hold that principles of equality and priority have no place in distributive ethics (Huseby, 2010, p. 180, n. 6). Casal distinguishes between a positive thesis, according to which 'it is important that everyone has enough,' and a negative thesis, which 'denies that either equality or priority has any role to play "at least above some critical threshold"' (Huseby, 2010, p. 179, quoting Casal, 2007, pp. 298-299). The version of the principle of sufficiency defended by Huseby implies the negative thesis.

${ }^{38}$ Huseby (2010, p. 185) emphasizes that these priority rules apply only 'between the sufficiency lines' and that 'what counts is not the value of benefits, but the disvalue of shortfalls.'

${ }^{39}$ Some writers argue on the basis of human rights for equal per capita shares of the capacity of the atmospheric sink. This group includes: Agarwal and Narain, 1991; Jamieson, 2001; Meyer, 2000; Singer, 2002. Henry Shue (1999/2010, p. 108), for example, argues that everyone should have 'enough for a decent chance for a reasonably healthy and active life of more or less normal length,' and that it is 'unfair not to guarantee everyone at least an adequate minimum' when circumstances are such that 'some people have less than enough for a decent human life, other people have far more than enough, and the total resources available are so great that everyone could have at least enough without preventing some people from still retaining considerably more than others have.' Shue's position can plausibly be construed as implying a human right to emit greenhouse gases up to the level of subsistence: Toft \& Hargrove, 2013, p. 221. This position is open to the criticism that while there is a right to secure access to the means to a decent life, fulfilling the latter right does not necessarily require greenhouse gas emissions, since economies can be based on renewable resources instead of fossil fuels: Hayward, 2009, pp. 432-433. The UN does not (to my knowledge) recognize climate-specific human rights, but its Human Rights Council emphasizes that climate change impacts basic rights such as the rights to life, to adequate food, to water, to health, and to adequate housing; it also impacts the self-determination of some peoples, including those living in low-lying island states: Human Rights Council, 2009, pp. 8-13, 20, 24.

${ }^{40}$ A conception of human rights grounded in a comprehensive moral doctrine (whether religious or secular) would conflict with the Law of Peoples if it justified a different list of human rights. However, if the lists overlap, then these rights simply have two justifications, and the rights on both lists can be justified in Rawlsian terms to people who do not endorse the comprehensive doctrine.

${ }^{41}$ Insofar as the human rights on which Caney bases his policy evaluations (rights to life, health, and subsistence) are included in Rawls' list, his approach may be compatible with the Law of Peoples and with the political conception of climate justice. Caney's (2010, pp. 166-169) formulations of the human rights to life, health, and subsistence appear to be fully compatible with the Law of Peoples, although his conception of global distributive justice conflicts with Rawls': see Caney, 2005b, and Bernstein, 2012a-2012b.

${ }^{42}$ At least two different stages of decision-making would be necessary because applying the third criterion (grave burdens that are readily relieved) would require full knowledge about the relevant empirical facts and particulars, including knowledge of the context of other policies in which this particular policy would get enacted. If the first stage of decision-making must take place behind a veil of ignorance, then 
the veil must be lifted to some extent for the second stage. Compare what Rawls says about his two principles for a just democratic society: 'The principles of justice are adopted and applied in a four-stage sequence' (Rawls, 2001, p. 48; see also pp. 112-114, 172-174).

${ }^{43}$ The Law of Peoples does not presuppose that people can be content only in liberal societies of one kind or another, nor that people living in decent non-liberal societies cannot be content.

${ }^{44}$ This would be a sufficiency principle like Huseby's, but omitting his strong assumption about the conditions (probably) necessary for contentment and instead including a weaker assumption to the effect that living in a decent society is necessary for contentment.

${ }^{45}$ This is one of various proposals for taxing natural resources. Another proposal, which has been widely discussed, is the Global Resources Dividend proposed by Thomas Pogge (2002, pp. 202-221).

${ }^{46}$ For this reason it seems that following Miller's suggestion for using a veil of ignorance would require raising the veil either once (fully, i.e., making all information available) or else more than once (by degrees). Raising the veil by degrees seems necessary.

${ }^{47}$ In 2011 the Green Climate Fund was designated as an operating entity of the financial mechanism of the UNFCCC, in accordance with Article 11 of the Convention. 'The fund will pursue a country-driven approach and promote and strengthen engagement at the country level through effective involvement of relevant institutions and stakeholders' (Green Climate Fund, 2015). 'While the Governing Instrument of the GCF states that developed countries will provide the bulk of GCF financial inputs, the Board decided to allow for flexibility in resourcing. Initially, it will only accept grants from the public and private sector, paid-in public capital contributions and concessional public loans. Over time, it may attract other forms of finance from the private or philanthropic sector, including from institutional investors, as well as from alternative sources (for example new taxes or levies from which funding might be raised for the GCF)' (Overseas Development Institute, 2014, p. 4).

${ }^{48}$ For discussions of philosophical issues relevant to corrective justice, see, e.g.: Caney, 2005a, pp. 747775; Gardiner, 2011, pp. 399-437; Garvey, 2008, pp. 66-80; Meyer, 2013, pp. 597-614; Miller, 2010, pp. 95-96; Moellendorf, 2009, pp. 106-131.

${ }^{49}$ Neither am I here endorsing any specific demands for corrective justice applied to the climate treaty.

${ }^{50}$ Posner and Weisbach (2010, p. 76) write: 'perhaps the obligations of nations should be determined by invoking John Rawls' idea of a "veil of ignorance": What principles of justice would reasonable people select if they were deprived of information about their own circumstances, including the nation in which they find themselves? Very plausibly, people would choose principles that would require those in rich countries to give a great deal to those in poor countries, especially if the latter are at serious risk.' The endnote attached to the last quoted sentence, n. 6 on p. 208, does not cite Rawls, but instead Martha Nussbaum and Steve Vanderheiden. Nussbaum is well known as a critic of the Law of Peoples.

${ }^{51}$ In support of their description of Rawls' view they cite only writings by two other authors, only one of whom (Nussbaum) has published much about Rawls. When citing Rawls directly (which they do only once, if I'm not mistaken), they refer only to an article he published in 1964, three decades before his publications on the Law of Peoples.

${ }^{52}$ Benjamin Sachs' criticism of their use of this term is partly distinct from, but compatible with, the criticism I offer here: see Sachs, 2014, p. 215.

${ }^{53}$ In Rawls' conception of a just liberal democratic society, justice as fairness, such questions are governed by the difference principle, which is part of the second of his two principles of domestic social justice: see Rawls, 2001, p. 43. 
${ }^{54}$ Robert Huseby argues that climate justice can be adequately addressed from the perspective of Rawls' theory of international justice, if it is further developed. He proposes adding a ninth principle to the Law of Peoples: 'Peoples recognize that adverse effects of climate change may undermine or threaten to undermine the prospects of most (if not all) peoples and societies to establish and/or maintain internally just or decent well-ordered institutions. This will, by implication, undermine or threaten to undermine the role of The Law of Peoples in regulating and expanding a peaceful and stable Society of Peoples. Therefore, just and decent peoples have an interest in undertaking, and a duty to undertake, the measures necessary to prevent such adverse effects from materializing, and to alleviate them when and where they do materialize' (Huseby, 2013, p. 234). Huseby contends that this amendment 'would only be a first, but crucial, step toward developing more specific schemes for distributing the burdens following from climate change' (Huseby, 2013, p. 242).

${ }^{55}$ As Nussbaum (2013, p. 471) points out, '[Posner and Weisbach] do not define deontology, and they offer only a glancing definition of welfarism.'

56 'Sustainable development is development that meets the needs of the present without compromising the ability of future generations to meet their own needs' (World Commission on Environment and Development, 1987, p. 43).

\section{References}

Agarwal, A., \& Narain, S. (1991). Global warming in an unequal world: A case of environmental colonialism. New Delhi: Center for Science and Environment.

Bernstein, A. R. (2000). Human rights reconceived: A defense of Rawls' law of peoples. (Unpublished doctoral dissertation). Harvard University, Cambridge, Massachusetts.

Bernstein, A. R. (2006). A human right to democracy? Legitimacy and intervention. In R. Martin \& D. Reidy (Eds.), Rawls's law of peoples: A realistic utopia? (pp. 278-298). Malden: Blackwell.

Bernstein, A. R. (2007a). Human Rights, Global Justice, and Disaggregated States: John Rawls, Onora O'Neill, and Anne-Marie Slaughter. American Journal of Economics and Sociology, 66(1), Reprinted in S.V. Hicks \& D.E. Shannon (Eds.), The Challenges of Globalization: Rethinking Nature, Culture, and Freedom (pp. 87-111). Oxford: Blackwell. http://dx.doi.org/10.1111/j.1536-7150.2007.00499.x.

Bernstein, A. R. (2007b). Justifying universal human rights via Rawlsian public reason. Archiv für Rechts und Sozialphilosophie, 108, 90-103.

Bernstein, A. R. (2008a). Kant on rights and coercion in international law: Implications for humanitarian military intervention. Jahrbuch für Recht und Ethik, 16, 57-98.

Bernstein, A. R. (2008b). Nussbaum versus Rawls: Should feminist human rights advocates reject the law of peoples and endorse the capabilities approach? In P. Des Autels \& R. Whisnant (Eds.), Global feminist ethics (pp. 117-137). New York: Rowman and Littlefield.

Bernstein, A. R. (2009). Kant, Rawls, and cosmopolitanism: Toward perpetual peace and the law of peoples. Jahrbuch für Recht und Ethik, 17, 3-50.

Bernstein, A. R. (2012a). Caney, Simon. In D. Chatterjee (Ed.), Encyclopedia of global justice (pp. 100-102). Berlin: Springer.

Bernstein, A. R. (2012b). Climate justice. In D. Chatterjee (Ed.), Encyclopedia of global justice (pp. 144-149). Berlin: Springer.

Bernstein, A. R. (2012c). Law of peoples. In D. Chatterjee (Ed.), Encyclopedia of global justice (pp. 635-639). Berlin: Springer.

Bernstein, A. R. (2012d). Moral cosmopolitanism. In D. Chatterjee (Ed.), Encyclopedia of global justice (pp. 711-717). Berlin: Springer.

Bernstein, A. R. (2012e). Original position. In D. Chatterjee (Ed.), Encyclopedia of global justice (pp. 786-790). Berlin: Springer.

Bernstein, A. R. (2012f). Political cosmopolitanism. In D. Chatterjee (Ed.), Encyclopedia of global justice (pp. 857-863). Berlin: Springer.

Bernstein, A. R. (2012g). Second original position. In D. Chatterjee (Ed.), Encyclopedia of global justice (pp. 979-983). Berlin: Springer. 
Bernstein, A. R. (2013). War as means to peace? Kant on international right. Jahrbuch für Recht und Ethik, 21, 237-259.

Bernstein, A. R. (2014). The rights of states, the rule of law, and coercion: Reflections on Pauline Kleingeld's 'Kant and cosmopolitanism'. Kantian Review, 19(2), 233-249. doi: http://dx.doi.org/10.1017/S136941541400003X.

Broome, J. (2012). Climate matters: Ethics in a warming world. New York, NY: W.W. Norton and Company.

Caney, S. (2005a). Cosmopolitan justice, responsibility, and global climate change. (pp. 747-775). Leiden Journal of International Law In S. M. Gardiner, S. Caney, D. Jamieson, \& H. Shue (Eds.), Climate ethics: Essential readings (pp. 122-145). Oxford: Oxford University Press.

Caney, S. (2005b). Justice beyond borders: A global political theory. Oxford: Oxford University Press.

Caney, S. (2010). Climate change, human rights, and moral thresholds. In S. M. Gardiner, S. Caney, D. Jamieson, \& H. Shue (Eds.), Climate ethics: Essential readings (pp. 163-177). Oxford: Oxford University Press.

Casal, P. (2007). Why sufficiency is not enough. Ethics, 117(2), 296-326. doi: http://dx.doi.org/10.1086/510692.

Casal, P. (2011a). Global taxes on natural resources. Journal of Moral Philosophy, 8(3), 307-327.

Casal, P. (2011b). Rejoinder to Pogge and Steiner. Journal of Moral Philosophy, 8(3), 353-365.

Casal, P. (2012). Progressive environmental taxation: A defence. Political Studies, 60(2), 419-433. doi: http://dx.doi.org/10.1111/j.1467-9248.2011.00924.x.

Cohen, J. (2010). Rousseau: A free community of equals. Oxford: Oxford University Press.

Embajada de Brasil. (2014). Declaración del Embajador José Antonio Marcondes de Carvalho Subsecretario General de Medio Ambiente, Energía, Ciencia y Tecnología: Ministerio de Relaciones Exteriores BRASIL en la Sesión Ministerial del ADP Bonn. 06 de junio de 2014. Retrieved 29/12/2014 from http://www.perubrasil.com/system/embajadabrasil/gallery_sub_article.asp?codigo $=510 \&$ status $=17$.

Gardiner, S. M. (2011). A perfect moral storm: The ethical tragedy of climate change. Oxford: Oxford University Press.

Garvey, J. (2008). The ethics of climate change: Right and wrong in a warming world. London: Continuum.

Green Climate Fund. (2015). Background. Retrieved on 01 February 2015 from http://www.gcfund.org/about/ the-fund.html.

Guruswamy, L. D. (1997/2012). International environmental law in a nutshell. St. Paul, Minnesota: Thomson Reuters.

Gutting, G., \& Jamieson, D. (2015). What can we do about climate change? New York Times. Retrieved from www.opinionator.blogs.nytimes.com.

Hayward, T. (2009). Human rights versus emissions rights: Climate justice and the equitable distribution of ecological space. Ethics and International Affairs, 21.

Human Rights Council. (2009). Report of the Office of the United Nations High Commissioner for Human Rights on the relationship between climate change and human rights. [A/HRC/10/61]. Retrieved from http://www.ohchr.org/Documents/Press/AnalyticalStudy.pdf.

Huq, S., \& Richards, J. -A. (2014). Big oil must pay for climate change harm to world's poorest. RTCC News. Retrieved from http://www.rtcc.org/2014/12/04/big-oil-must-pay-for-climate-change-harm-to-worldspoorest/\#sthash.29Cd2ZlL.dpuf.

Huseby, R. (2010). Sufficiency: Restated and defended. Journal of Political Philosophy, 18(2)

Huseby, R. (2013). Climate Change, Sustainability, and Environmental Ethics. Environmental Ethics, 35(2). doi: http://dx.doi.org/10.5840/enviroethics201335219.

Intergovernmental Panel on Climate Change. (2014). Climate change 2014: Synthesis report. Contribution of Working Groups I, II and III to the Fifth Assessment Report of the Intergovernmental Panel on Climate Change [Core Writing Team, R.K. Pachauri and L.A. Meyer (eds.)]. IPCC, Geneva, Switzerland, 151 pp. (Here cited as required. Retrieved from https://www.ipcc.ch/report/ar5/syr/).

Jamieson, D. (2001). Climate change and global environmental justice. In P. Edwards \& C. Miller (Eds.), Changing the atmosphere: Expert knowledge and global environmental governance (pp. 287-308). Cambridge, MA: MIT Press.

Jamieson, D. (2013). Climate change, consequentialism, and the road ahead. Chicago Journal of International Law, 13, 439-468.

Meyer, A. (2000). Contraction and convergence: The global solution to climate change. Cambridge, UK: Green Books.

Meyer, L. H. (2013). Why historical emissions should count. Chicago Journal of International Law, 13, 597-614. 
Miller, R. W. (2010). Globalizing justice: The ethics of poverty and power. Oxford: Oxford University Press.

Moellendorf, D. (2009). Global inequality matters. New York: Plagrave Macmillan.

Nussbaum, M. C. (2013). Climate change: Why theories of justice matter. Chicago Journal of International Law, $13,469-488$.

Overseas Development Institute. (2014). The green climate fund. Retrieved on 01 February 2015 from http:// www.odi.org/sites/odi.org.uk/files/odi-assets/publications-opinion-files/9376.pdf.

Pogge, T. (2002). World poverty and human rights. Malden, MA: Polity Press.

Posner, E. A., \& Weisbach, D. (2010). Climate change justice. Princeton, NJ: Princeton University Press.

Posner, E. A., \& Weisbach, D. (2013). International paretianism: A defense. Chicago Journal of International Law, 13, 347-358.

Priest, M. (2014). 'Dead rat' deal saves Lima climate summit. Australian Financial Review. Retrieved from http://www.ipe.net.au/wp-content/uploads/2014/12/Dead-rat.pdf.

Rawls, J. (1993). The law of peoples. In S. Freeman (Ed.), John Rawls: Collected papers (pp. 529-564). Cambridge, MA: Harvard University Press.

Rawls, J. (1993, rev. 1996, 2005). Political liberalism. New York: Columbia University Press.

Rawls, J. (1999). The law of peoples. Cambridge, MA: Harvard University Press.

Rawls, J. (2001). Justice as fairness: A restatement. Cambridge, MA: Harvard University Press.

Rawls, J. (2007). Lectures on Mill. In S. Freeman (Ed.), John Rawls: Lectures on the history of political philosophy (pp. 251-316). Cambridge, MA: Harvard University Press.

Rawls, J. (2007b). Lectures on Rousseau. In S. Freeman (Ed.), John Rawls: Lectures on the history of political philosophy (pp. 191-248). Cambridge, MA: Harvard University Press.

Sachs, B. (2014). The relevance of distributive justice to international climate change policy. Ethics, Policy \& Environment, 17(2), 208-224. doi: http://dx.doi.org/10.1080/21550085.2014.926085.

Shue, H. (1999). Global environment and international inequality. International Affairs, 75(3), 531-545, As reprinted in S.M. Gardiner, S. Caney, D. Jamieson \& H. Shue (Eds.), Climate Ethics: Essential Readings (pp. 101-111). Oxford: Oxford University Press. http://dx.doi.org/10.1111/1468-2346.00092.

Singer, P. (2002). One world. New Haven, CT: Yale University Press.

Sovacool, B. K., Sidortsov, R. V., \& Jones, B. R. (2014). Energy security, equality, and justice. New York: Routledge.

Stern, T. D. (2014). Seizing the opportunity for progress on climate: Remarks of October 14, 2014. Retrieved from http://www.state.gov/s/climate/releases/2014/232962.htm.

Taraska, G., \& Vogel, J. (2014). Outcomes of the Lima climate negotiations: Essential steps toward an international climate agreement. Retrieved from https://www.americanprogress.org/issues/green/ news/2014/12/18/103534/.

Toft, K.H., \& Hargrove, E.C. (2013). The human rights approach toclimate change. EnvironmentalEthics, 35(2). doi: http://dx.doi.org/10.5840/enviroethics201335218.

World Commission on Environment and Development. (1987). Our common future. New York: Oxford University Press.

World Resources Forum. (2013). Resource efficiency, governance and lifestyles - WRF 2013 Davos meeting report. Retrieved from http://www.wrforum.org/wrfpublicationspdf/wrf-2013-davos-meeting-report/. 